\title{
Rituele dynamiek en rivaliteit: Kristallnachtherdenkingen in Amsterdam (1992-2019)
}

Sipco Vellenga ad Gerard Wiegers*,1

\section{Summary}

Two different Kristallnacht commemorations are presently held in Amsterdam each year, in close proximity to one another and on the same day but organised by different groups. What is the reason for this? Why do people who wish to commemorate the terrible events of Kristallnacht not hold a joint annual remembrance ceremony? Does this division coincide with the boundaries between Jewish and Muslim communities? After introducing the theme, presenting the theoretical approach and describing the history of Kristallnacht commemoration in Amsterdam, this article analyses the growing discord between the two organizing groups. It relates this development to different goals, views and interests of these groups, their shifting societal positions, and to developments in the national and international context. We argue that the increasing discord does not stem so much from differences of religious ideas between the Jewish and Muslim communities, but rather from political differences of opinion that draw dividing lines within communities.

\section{Introductie}

Er bestaan in Nederland verschillende soorten van herdenkingen rond de gebeurtenissen voorafgaande en tijdens de Tweede Wereldoorlog. De Kristallnachtherdenking is hier een van. ${ }^{2}$ Tijdens de Kristallnacht, op 9 november 1938, werden in Duitsland bij Joodse bedrijven en winkeliers ruiten ingegooid en 1.500 synagogen verwoest. Ongeveer 1.500 Joden werden tijdens en in de periode na de nacht gedood en 30.000 Joden werden door de Nazi's in concentratiekampen opgesloten. ${ }^{3}$ De Kristallnacht was het toneel van de eerste massale openbare geweldsuitbarsting tegen Joden in Nazi-Duitsland en, terugkijkend, een voorbode van de systematische Jodenvervolging en moorden die nadien zouden plaatsvinden.

* Sipco Vellenga is als universitair hoofddocent godsdienstsociologie verbonden aan de Faculteit Godgeleerdheid en Godsdienstwetenschap van de Rijksuniversiteit Groningen en Gerard Wiegers als hoogleraar Godsdienstgeschiedenis en Vergelijkende Religiewetenschap aan de afdeling Geschiedenis van de Faculteit der Geesteswetenschappen van de Universiteit van Amsterdam. 
In Amsterdam vinden sinds 2010 jaarlijks vrijwel gelijktijdig twee Kristallnachtherdenkingen plaats, de ene wordt sinds 2011 georganiseerd door het Platform Stop Racisme en Uitsluiting (PSRU) en, in 2017 en 2018, het Comité Kristallnachtherdenking, de andere door het Centraal Joods Overleg (CJO). ${ }^{4,5}$ De eerste herdenking gaat terug tot 9 november 1992. Zij werd georganiseerd door het antiracisme platform Nederland Bekent Kleur (NBK), de voorloper van het PSRU en het Comité Kristallnachtherdenking, in het centrum van Amsterdam. De directe aanleiding voor de organisatoren om deze herdenking te starten was een aanslag in Rostock (in het toenmalige OostDuitsland) op een asielzoekerscentrum en het leggen van een brandbom bij een moskee in Nederland. ${ }^{6}$ Dat juist geweld tegen asielzoekers en moslims de aanleiding vormde voor de herdenking is tot op de dag van vandaag een belangrijk gegeven gebleven. Antisemitisme, anti-fascisme, xenofobie en islamofobie hebben hierin steeds centraal gestaan. De twee leiders en oprichters van NBK waren René Danen en Abdou Menebhi, die beiden een geschiedenis hadden als activisten. Menebhi heeft een Marokkaanse achtergrond en was lange tijd voorzitter van het Komité Marokkaanse Arbeiders in Nederland (KMAN), een linkse, seculiere arbeidersorganisatie met, in de jaren tachtig, communistische sympathieën. Later werd hij voorzitter van de Stedelijke Marokkaanse Raad (Amsterdam) en werd hij actief in het Amsterdamse EuroMediterraan Centrum Migratie en Ontwikkeling (EMCEMO). Deze organisatie onderhoudt thans ook een meldpunt islamofobie. Marokkaanse en Turkse migrantenorganisaties steunden weldra het initiatief. De NBK-herdenking vond meestal plaats bij het Monument voor het Joodse verzet (1940-1945) op de Zwanenburgwal, dicht bij het Amsterdamse stadhuis (de Stopera) en de vroegere Joodse buurt, en sinds 2016 op andere plaatsen, zoals in het theater Perdu. Er worden kransen gelegd, er zijn sprekers, zoals Jaap Hamburger (Een ander Joods Geluid) in 2016, voormalig premier Dries van Agt in 2017 en de historica Nadia Bouras in 2018, er wordt muziek gemaakt, en proza en poëzie gelezen. Met uitzondering van het jaar 2000 (toen de organisatie meewerkte aan een landelijke Kristallnachtmanifestatie) en de jaren 2004-2007 heeft deze herdenking tot 2018 onafgebroken plaatsgevonden.

De tweede herdenking wordt sinds 2003, dus negen jaar na het begin van de NBK-herdenkingen, georganiseerd door het Centraal Joods Overleg Externe Belangen (CJO). Het CJO werd in 1997 opgericht en heeft ten doel de belangen van de Joodse gemeenschap in Nederland naar buiten toe te behartigen. In het CJO participeren naast de drie joodse kerkgenootschappen: het Nederlands-Israëlitisch Kerkgenootschap (NIK), het Nederlands Verbond voor Progressief Jodendom (NVPJ) en het Portugees-Israëlitisch Kerkgenootschap 
(PIK), onder meer de Federatie Nederlandse Zionisten (FNZ), de Stichting Joods Maatschappelijk Werk (JMW) en het Centrum Informatie en Documentatie Israël (CIDI). Bij de belangenbehartiging van het CJO valt te denken aan zaken als restitutie van oorlogstegoeden, herdenken, beveiliging, antisemitisme en dialoog met andere religies. Van belang is, zo zullen we ook in het vervolg zien, dat het CJO zich uitsluitend bezighoudt met zaken in Nederland. Kwesties die bijvoorbeeld Israël betreffen, liggen volgens afspraak in de Joodse gemeenschap op het terrein van organisaties als CIDI en FNZ.

In 2000 ondersteunde het CJO een landelijke manifestatie ter herdenking van de Kristallnacht die de gemeente Amsterdam organiseerde. Na een aantal incidenten met de organisatoren van de NBK-herdenkingen organiseerde het CJO in 2003 voor het eerst een eigen herdenking. In 2008 herhaalde het CJO dit en vanaf 2010 organiseerde het ieder jaar zijn eigen herdenking die sinds 2014 door deze instantie naarmate de verwijdering van de andere herdenking toenam meer en meer als de "officiële" en sinds 2017 als de "Nationale Kristallnachtherdenking” wordt aangeduid. De herdenkingen van het CJO vinden plaats in en bij de Portugese synagoge, de Esnoga, en worden gevolgd door een kranslegging bij het gebouw van de Hollandse Schouwburg, dat in de oorlog als verzamelplaats had gediend voor Joden die werden gedeporteerd naar de concentratiekampen. De laatste jaren voeren vele politici en bestuurders het woord tijdens deze herdenkingen, zoals in 2016 minister-president Mark Rutte, in 2017 de huidige Tweede Kamer voorzitter, Khadija Arib, en in 2018 de voormalig voorzitter van de Tweede Kamer en huidige voorzitter van het Nationaal Comité 4 \& 5 mei, Gerdi Verbeet.

De situatie van het naastelkaar bestaan van twee Kristallnachtherdenkingen in Amsterdam roept de vraag op hoe het herdenken van de Kristallnacht in Amsterdam zich de afgelopen decennia precies heeft ontwikkeld en hoe die ontwikkeling begrepen kan worden. Daarbij is tevens de vraag van belang wat de huidige verdeeldheid tussen de twee herdenkingen zegt over de relatie tussen Joden en moslims in Amsterdam en elders in Nederland.

Om deze vragen te beantwoorden, zullen we eerst het theoretisch perspectief uiteenzetten van waaruit we de thematiek benaderen. Vervolgens beschrijven we de geschiedenis van de beide herdenkingen in hun onderlinge dynamiek en rivaliteit. We starten met de voorgeschiedenis, focussen daarna op de periode van 1992-2009 waarin er, met uitzondering van 2003 en 2008, jaarlijks herdenkingen plaats vonden en gaan vervolgens in op de situatie sinds 2010 waarin er twee jaarlijkse herdenkingen naast elkaar in Amsterdam bestaan. Aansluitend maken we de balans op en analyseren we de getraceerde ontwikkeling door deze te verbinden met specifieke kenmerken van de 
instellingen die de manifestaties organiseren, de maatschappelijke posities die zij innemen, alsmede met enkele elementen uit de (internationale) context waarin zij functioneren. We sluiten af met een 'tot besluit' waarin we stil staan bij de betekenis van de huidige rivaliteit tussen de twee besproken herdenkingen voor de Joods-islamitische betrekkingen in Nederland.

Bij de beantwoording van de vragen baseren we ons in de eerste plaats op beschikbare publicaties over de geschiedenis van de Kristallnachtherdenkingen in Nederland. De meest uitvoerige publicatie is een nuttig, kort overzicht opgesteld door Roemer van Oordt en Ewoud Butter dat online is gepubliceerd op de website Republiek Allochtonië, waarin de auteurs de dynamiek van het conflict trachten bloot te leggen (2015). Daarnaast gaat de historicus Remco Ensel in zijn monografie Haatspraak (2014) in op de Kristallnachtherdenking in Amsterdam en besteedt hij aan dit onderwerp aandacht in de studie The Holocaust, Israel en 'the Jew' die hij samen met Evelien Gans heeft uitgebracht (2017). Verder is sprake van een aantal meer persoonlijke, essayistisch getinte publicaties, bijvoorbeeld van de journalisten Natascha van Weezel (2017) en Maarten-Jan Hijmans. Hijmans houdt al jaren een weblog bij over het Israëlisch-Palestijnse conflict en de doorwerking daarvan in Nederland, genaamd 'abu-pessoptimist'. In aanvulling op de hierboven genoemde bronnen, hebben we gebruik gemaakt van websitemateriaal van de verschillende organisaties, krantenarchieven, archiefmateriaal dat bewaard wordt in het Instituut voor Sociale Geschiedenis en drie interviews, te weten met Pieter Jan van Slooten (strategisch adviseur Gemeente Amsterdam) op 16 maart 2018, met Ronny Naftaniel (voormalig directeur CIDI; vicevoorzitter CJO) op 19 oktober 2018 en met Maarten-Jan Hijmans (actief betrokken bij NBK, PSRU en Comité Kristallnachtherdenking, 2011-2019) op 21 juni 2019.

\section{Theoretisch perspectief}

Wij benaderen de relatie tussen de twee Kristallnachtherdenkingen in Amsterdam vanuit het perspectief van het werk van de Franse socioloog Pierre Bourdieu (1986; 1990; 1999). Vanuit dit perspectief bevinden deze herdenkingen zich op een bepaald 'veld', te weten het culturele veld van herdenkingen in Nederland van gebeurtenissen voorafgaande aan en tijdens de Tweede Wereldoorlog. Op dit veld hebben de organisaties van de twee herdenkingen zich in de loop van de tijd ontwikkeld tot elkaars rivalen; beide streven hetzelfde 'culturele kapitaal' na, namelijk het houden van de belangrijkste, jaarlijks terugkerende herdenking van de Kristallnacht in Nederland. 
Om dit culturele kapitaal te verwerven, zijn ze in een strijd verwikkeld om (media)-aandacht, publieke waardering en erkenning, en legitimiteit. In dit culturele kapitaal is er ook een 'spirituele' dimensie aanwezig (vgl. Verter 2003, 152). Met een variatie op het werk van de godsdienstsociologe Danièle Hervieu-Léger manifesteert spiritualiteit zich hier als een keten van herinnering waarin heden, verleden en toekomst nauw met elkaar verbonden zijn (Hervieu-Léger 2000).

In de analyse van de rivaliserende relatie tussen de beide instellingen op het genoemde culturele veld van herdenkingen in Nederland onderscheiden we drie typen factoren: institutionele factoren, positionele factoren en contextuele factoren. Institutionele factoren houden verband met specifieke kenmerken van de organiserende instellingen, zoals hun doelstellingen, hun visie op thema's zoals de verhouding tussen Israël en de Palestijnen, antisemitisme en het verschijnsel van islamofobie. Tussen en binnen deze instellingen treffen we ook het mechanisme van 'selfing' en 'othering' aan (Baumann 2004; Brandsma 2019). Positionele factoren betreffen de positie die de instellingen in de omringende samenleving innemen. Vooral de positie in het nationale zelfbeeld is van belang (vgl. Macdonald 2005; Katz 2015; Wallet 2017). Een positie in de marge zet groeperingen sterk aan om voor hun eigen belang op te komen en zaken die hen aangaan zelf ter hand te nemen. De categorie contextuele factoren bestaat uit factoren die vanuit de omgeving invloed uitoefenen op de verhoudingen tussen de instellingen. Te denken valt aan het optreden van significante externe instellingen, zoals instellingen in het religieuze veld: de moslimgemeenschappen en de christelijke kerken en voorts de gemeentelijke overheid, alsmede aan internationale ontwikkelingen, zoals de opkomst van het verschijnsel islamofobie en de veranderende visie in Nederland op het beleid van de Israëlische regering ten aanzien van Palestijnen.

\section{Voorgeschiedenis}

De eerste contacten tussen een aantal belangrijke organisaties en personen die later een rol gaan spelen bij de Kristallnachtherdenkingen gaan terug tot op de jaren zeventig en tachtig van de twintigste eeuw. Van Weezel noemt als vroegste historische gebeurtenis een gezamenlijk initiatief tegen fascisme en antisemitisme $(2017,54)$. Op 14 december 1980 werd een manifestatie in de Jaap Eden Hal georganiseerd, die begon met een kranslegging bij de Dokwerker, waarin, zo meldt de communistische krant, De Waarheid, Ronny Naftaniel (aangeduid als lid van de Liberaal Joodse Gemeente) en Abdou 
Menebhi (namens het KMAN en de Marokkaanse gemeenschap) een krans legden (15 en 16 december 1980). ${ }^{7}$

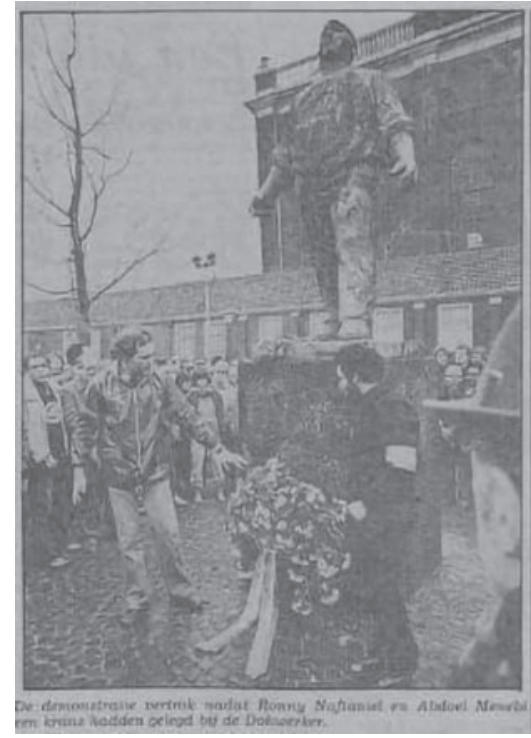

Uit: Van der Valk $(1996,14)$

In dit initiatief verenigden zich op dat moment tachtig zeer uiteenlopende organisaties, waaronder de Liberaal Joodse Gemeente en "buitenlandse arbeiders" die Amsterdam als de "stad van de Dokwerker" wilden tonen: verenigd tegen fascisme en antisemitisme, zoals het geven van de schuld aan vreemdelingen voor de woningnood in de stad, maar ook de niet-Jood verklaringen die de Rijn-Schelde-Verolme Machinefabrieken en Scheepswerven NV (RSV) had uitgegeven. De directe aanleiding was een bomaanslag op de synagoge in Parijs en aanslagen op Joodse instellingen in Wenen en Antwerpen, alsmede aanslagen van de zijde van 'neo-nazi's' (De Waarheid 12 december 1980). ${ }^{8}$

In 1988 ontstond ophef in de media. Er verscheen een artikel van de hand van de journaliste Anet Bleich in De Groene Amsterdammer waarin het KMAN werd geassocieerd met een brochure die kennelijk inmiddels breed verspreid was (1988). De brochure in kwestie is de 'Intifada special', een éénmalige uitgave van het Solidariteitsplatform met de volksopstand in Palestina (1988). Over de brochure schreef Bleich dat deze tal van antisemitische stereotypen bevatte. Het Palestina Komitée had de brochure aanvankelijk mede ondertekend, maar distantieerde zich er al snel van. Het KMAN hield zich aanvankelijk op de vlakte, maar nam later toch ook afstand van de strekking van deze brochure. 
In september 1989 ontstond een conflict tussen KMAN (en een aantal Marokkaanse organisaties in Amsterdam) en het CIDI rond de oprichting van een nieuw antidiscriminatiebureau in Amsterdam (Het Parool, 26 september 1989). Het KMAN weigerde het CIDI een zetel in het op te richten bestuur van dit bureau toe te staan. Zij zag het CIDI als een politieke organisatie die "Arabieren als terroristen beschouwt" (NRC Handelsblad, 26 september 1989). De directeur van het CIDI, Ronny Naftaniel, verdedigde zich tegen deze aantijging door erop te wijzen dat het CIDI een professionele Joodse organisatie was met een lange staat van dienst wat betreft de strijd tegen discriminatie en antisemitisme en dat hijzelf nog met Menebhi samen een krans had gelegd bij het standbeeld van de Dokwerker. Naftaniel was vanaf 1976 bij het CIDI (opgericht in 1974) werkzaam. Hij richtte zich daarbij, naast vormgeven aan het steunen van Israël, op twee thema's: strijd tegen antisemitisme en dialoog met andere minderheden (Van Weezel 2017, 53). In dit conflict werd bemiddeld door het landelijk Bureau Racisme Bestrijding.

\section{Eén herdenking (1992-2009)}

In 1992 startte het platform NBK met de Kristallnachtherdenkingen te Amsterdam. Dit initiatief werd in de loop van de tijd ondersteund door een brede coalitie van organisaties, waaronder vakbonden, Marokkaanse en Turkse migrantenorganisaties, het Nederlands Auschwitz Comité, de GKN en de NHK en na 2004 de PKN, Amsterdams 4 en 5 Mei Comité, Meldpunt Discriminatie Amsterdam, Kerk in Actie, de Anne Frankstichting, en de Internationale Socialisten. Ook de Joodse organisaties Haboniem, BBJo (Joodse jongerenorganisatie), Een Ander Joods Geluid (EAJG), bijvoorbeeld in de persoon van voorzitter Jaap Hamburger, deden mee. Daarnaast was er deelname van Joodse overlevenden van de Holocaust, zoals Mirjam Ohringer, en rabbijnen, zoals Edward van Voolen en Awraham Soetendorp. Ook verzorgden Joodse musici vaak de muzikale begeleiding.

In de jaren negentig van de vorige eeuw verliepen de herdenkingen zonder incidenten. De participanten straalden eensgezindheid uit in hun afkeer van antisemitisme, maar ook van andere vormen van racisme en vreemdelingenhaat. De belangstelling voor de herdenkingen groeide. Amsterdam was ook niet meer de enige plek waar de Kristallnacht werd herdacht. In bijvoorbeeld Groningen, Leeuwarden, Breda, bij het voormalig kamp Westerbork en bij het Nationaal Bevrijdingsmuseum vonden herdenkingen plaats. Alle Nederlandse herdenkingen werden ondersteund door het NBK en hadden een eigen lokaal karakter (demonstraties, muziek, fakkeltochten etc.). NBK had een 'trekkersrol', 
maar werkte samen met vele organisaties, voornamelijk het Comité 4 \& 5 mei Amsterdam en Stichting Meldpunt Discriminatie Amsterdam.

\section{Oplopende spanningen}

Vanaf het einde van de jaren negentig kwamen bij de herdenkingen spanningen aan het licht die hun wortels hadden in de geschetste voorgeschiedenis en met name het conflict tussen KMAN en Joodse personen en groeperingen. In 2000 werd in plaats van de gebruikelijke herdenking een landelijke manifestatie georganiseerd, die vanwege het grote aantal deelnemers plaatsvond bij de Dokwerker. Het initiatief kwam van de Europese stichting UNITED for Intercultural Action. ${ }^{9}$

Tijdens de landelijke manifestatie in Amsterdam werd Abdou Menebhi door Jacques Grishaver, de voorzitter van het Nederlands Auschwitz Comité, gemaand om het podium te verlaten toen hij, in weerwil van eerder gemaakte afspraken, begon te spreken over Israël (Ensel \& Gans 2017, 486). Menebhi stelt hierover in een later gepubliceerd interview het volgende:

"In de weken daarvoor waren in verschillende Amsterdamse buurten door Marokkaanse jongeren leuzen tegen joden op muren gekalkt. Aanleiding hiervoor was de tweede intifada die in oktober 2000 was uitgebroken nadat Sharon een bezoek aan de Tempelberg had gebracht. We hebben toen Marokkanen gemobiliseerd om aanwezig te zijn bij de Kristallnachtherdenking om hun solidariteit te betonen met de joodse gemeenschap. Dat was succesvol. Ik heb tijdens mijn toespraak nadrukkelijk herhaald dat antisemitische leuzen onacceptabel waren. Ik ben tegen iedere vorm van racisme en discriminatie, waar ook ter wereld. Daarom heb ik in mijn speech opgeroepen geen ruimte te geven aan extremisten, geweld en onderdrukking. In dat verband heb ik ook het optreden van Israël in de bezette gebieden genoemd. Dat mocht ik niet doen, omdat de herdenking van de Kristallnacht volgens sommigen niet over het buitenland mocht gaan" (Van Oordt \& Butter 2015).

Ensel werpt een ander licht op deze zaak. Uit archiefdocumenten over deze herdenking blijkt dat eerder de volgende afspraak over de gang van zaken was gemaakt: “De bijeenkomst is niet politiek gekleurd en er zal niet gesproken worden over het conflict in het Midden-Oosten, behalve wanneer dat is in algemene zin dat conflicten, waar die ook ter wereld plaatsvinden nooit een reden mogen zijn om in Nederland banden van solidariteit tussen mensen te verbreken" (Ensel 2014, 386).

Zijn optreden werd Menebhi met name in Joodse kring niet in dank afgenomen. Desalniettemin bleef NBK de herdenking organiseren en bleven 
vertegenwoordigers uit de Joodse gemeenschap hieraan meewerken. De discussies tussen de partijen over vorm en inhoud bleven (Van Oordt \& Butter 2015). In 2003 organiseerde het CJO in samenwerking met politieke partijen en religieuze organisaties (Samen-op-Weg Kerken, Bisschoppenconferentie en $\mathrm{CMO}$ in oprichting) voor het eerst een eigen herdenking en uitte het voornemen dit iedere vijf jaar te gaan doen. Bij die herdenking, die plaatsvond bij het monument voor het Joodse verzet en zeer grote belangstelling trok, voerde namens het Contactorgaan Moslims en Overheid (CMO) Selami Yüksel het woord. Hij constateerde een toenemende verwijdering tussen Joodse en islamitische burgers en riep op tot het zoeken van toenadering en dialoog. Hij vond het onacceptabel om de conflicten elders in de wereld uit te vechten in Nederland. Andere sprekers waren Job Cohen, de burgemeester van Amsterdam, Frits Bolkestein, VVD-politicus en Eurocommissaris. De laatste wees moslims aan als de hoofdverantwoordelijken voor de toename van het zogenaamde 'nieuwe antisemitisme', zoals hij het herlevende antisemitisme aanduidde. Hieronder komen we op dit verschijnsel terug. Tussen 2003 en 2007 werden geen herdenkingen georganiseerd, waarschijnlijk vanwege een gebrek aan vrijwilligers (Van Oordt \& Butter 2015). In 2004 ontstond groot ongenoegen toen op 27 maart, in het kader van een protest in Amsterdam tegen het Israëlische nederzettingenbeleid tijdens de Dag tegen Racisme, EMCEMO (opvolger van KMAN), Internationale Socialisten en de Arabisch Europese Liga (EAL) aandacht hadden besteed aan de Israëlische raketaanval op Hamas kopstuk en stichter Ahmad Yasin in Gaza, waarbij Yasin en andere Palestijnen de dood vonden (vgl. Mol 2004).

\section{Thema's van verdeeldheid: Islamofobie en het Israëlisch-Palestijns conflict}

In 2008 was het 70 jaar geleden dat de Kristallnacht (1938) had plaatsgevonden en in dat jaar hervatte NBK de herdenking. Speciale aandacht werd, onder meer door spreker Ed van Thijn, geschonken aan racisme, antisemitisme en islamofobie. Dezelfde thema's als - bijvoorbeeld - in 2000. "Toch", zo stellen Van Oordt en Butter: "[...] viel dat laatste in 2008 opeens slecht bij delen van joods Nederland.” De hoofdredacteur van het Nieuw Israëlietisch Weekblad (NIW), Paul Damen, sprak in een column van een 'schandelijke', 'a-historische' en 'schaamteloze' bijeenkomst. De gelijkstelling van vermeende moslimhaat met de Kristallnacht vond hij "meeliften op andermans leed" (Van Oordt \& Butter 2015).

Volgens Daphne Meijer, journaliste, oud NIW-redactrice en van 2016-2019 EAJG-medewerker, lag islamofobie in die jaren gevoelig in Joodse kring omdat sommige Joden in die jaren iets zagen in de islam- en Israël-standpunten van 
de Partij voor de Vrijheid (PVV), de partij van Geert Wilders (geciteerd in Van Oordt \& Butter 2015). Sommigen sloten zich ook bij deze partij aan, zoals bijvoorbeeld het PVV Tweede Kamerlid Gidi Marcuszower. Meijer zag binnen de Nederlandse Joodse gemeenschap twee stromingen ontstaan: de eerste zag islamofobie en antisemitisme als twee verschijningsvormen van een vergelijkbare afkeer van 'de vreemdeling' of 'de ander', de tweede zag islamofobie en antisemitisme als twee elkaar uitsluitende fenomenen. "Het ene standpunt is gebaseerd op het zondebok-denken, waarbij nu eens de jood, en dan weer de moslim die rol vervult en het dus niet gaat om het jood- dan wel moslim-zijn, maar om de positie als paria in de samenleving. De andere redenering gaat uit van het idee dat de strijd tegen het antisemitisme de facto een strijd tegen moslims is, aangezien het antisemitisme, in elk geval in deze analyse, in zijn moderne verschijningsvorm als anti-Israëlisme en antizionisme vooreerst van moslims afkomstig is" (geciteerd in Van Oordt \& Butter 2015).

Meijer wijst erop dat een deel van de Joodse gemeenschap betrokken was en bleef bij de NBK-herdenkingen, onder wie leden van de Liberaal Joodse Gemeente (LJG) en Een Ander Joods Geluid (EAJG). Binnen dit deel wordt niet alleen een parallellie gezien tussen antisemitisme en islamofobie, maar tevens een kritischer houding ingenomen ten opzichte van de Israëlische politiek inzake het Israëlisch-Palestijnse conflict dan gebruikelijk is in de andere groep. Juist kritiek op de politiek van Israël in het kader van een herdenking van de eerste anti-Joodse pogrom die plaatsvond in 1938 ligt zeer gevoelig, zeker als die door niet-Joden wordt geïnitieerd. In relatie tot een dergelijke gevoeligheid wijst de psycholoog Nico Frijda erop dat de emoties verbonden met de onzekerheid over de mogelijke herhaling van een traumatische gebeurtenis uit het verleden enorme gevolgen kan hebben voor de wijze waarop ontwikkelingen in het heden kunnen worden ervaren (1997). Omdat kritiek op de politiek van Israël in Nederland in deze periode in toenemende mate een zaak van 'links' was geworden en de verdediging daarvan een zaak van 'rechts', kwam binnen de Joodse gemeenschap steeds scherper een politieke scheidslijn aan het licht (vgl. Malcontent 2018).

\section{Verdeeld herdenken (vanaf 2oIo tot heden)}

In 2010 ging de dynamiek en rivaliteit in de organisatie en de rituelen van herdenking een nieuwe fase in. In dat jaar besloot het CJO uit protest tegen het karakter van de bestaande herdenking tot een jaarlijkse eigen herdenking. Volgens de toenmalig directeur van het CIDI, Ronny Naftaniel, deed men 
dit: “omdat we niet kunnen accepteren dat de Jodenvervolging door organisaties en personen voor hun politieke agenda wordt misbruikt" (Het Parool, 10 november 2010). Men verweet het PSRU onder meer dat het in zijn aandacht voor misstanden in het buitenland eenzijdig kritiek uitoefende op Israël en voorbij ging aan bijvoorbeeld de situatie in tal van landen in het MiddenOosten waar moslimminderheden, Joden en christenen gediscrimineerd en soms vervolgd worden (interview Naftaniel).

De discussies tussen CJO en PSRU werden in deze periode zeer polemisch. Er vond discussie plaats over de anciënniteit, het karakter en de waardigheid van de herdenking. Zo schrijft het CIDI in 2011: "In 2010 blijkt dat de tussenliggende jaren zijn 'gekaapt' door de organisatie Nederland Bekent Kleur, met activist René Danen aan het hoofd. Nederland Bekent Kleur heeft nauwe banden met organisaties die Israël uitmaken voor een apartheidsstaat en die de huidige politieke verhoudingen in Nederland vergelijken met die in Duitsland vlak voor de Tweede Wereldoorlog. Kortom, de Kristallnachtherdenking wordt ingevuld met een politieke agenda. Na luide protesten uit onder meer de Joodse gemeenschap organiseert het CJO met behulp van het CIDI een waardige Kristallnachtherdenking in een bomvolle Esnoga in bijzijn van de Amsterdamse burgemeester Van der Laan. Kristallnacht wordt weer herdacht op de manier zoals het hoort" (CIDI 2011). De PSRU verklaart in 2014 dat het: "[...] in de aanvallen van de Joodse organisaties een poging [ziet] om pluriformiteit bij de herdenking van gebeurtenissen die te maken hebben met de Holocaust, de kop in te drukken. Het Platform vindt dit een verontrustende ontwikkeling. Het betreurt het ook dat het CJO het daarbij nodig vindt voortdurend dezelfde onwaarheden over onze herdenking te blijven herhalen" (PSRU 2014).

De CJO-herdenking verliep in 2011 als volgt. $\mathrm{Na}$ een openingstoespraak door CJO-voorzitter Willem Koster die erop wees dat de les van de Kristallnacht was dat racisme en antisemitisme gepaard gaand met de demonisering van Israël catastrofale gevolgen kunnen hebben, stelde deze tevens dat de onrust die was ontstaan over het heden afbreuk doet aan de herinnering aan de Kristallnacht. Vervolgens werd mevrouw Uschi Rubinstein, ooggetuige van de Kristallnacht, geïnterviewd door Esther Voet (CIDI). Hierna werd muziek van Kurt Weill uitgevoerd door onder andere David Kweksilber en Werner Herbers en was er een toespraak van de Amsterdamse burgemeester Eberhard van der Laan. Ingaande op wat hij een "gevoelig punt" noemde, besprak hij dat er op dat moment sprake was van twee herdenkingen en dat het stadsbestuur aan beide aandacht besteedde door zijn aanwezigheid. Toch, zo stelde hij, leidde die tweespalt af van waar het om gaat en vestigt het de aandacht op 
zaken die daarmee weinig te maken hebben. Het ging in zijn perspectief om het herdenken van het lot van Joden, toen en daar. Hij deed een oproep aan het PSRU om de dialoog met het CJO aan te gaan en het historisch karakter leidend te laten zijn in een zo mogelijk samen herdenken van de Kristallnacht.

Ondanks deze woorden is er geen oplossing gevonden. Het PSRU is sindsdien doorgegaan met de herdenking en blijven pleiten voor een agenda met daarop naast antisemitisme en racisme ook islamofobie en het IsraëlischPalestijnse conflict. In 2015 ontstond opschudding toen het Platform het Palestijnse Knessetlid Hanin Zoabi uitnodigde om het woord te voeren over de situatie van de Palestijnen (Gemeente Amsterdam 2015; Hijmans 2015).

\section{De tweespalt geanalyseerd}

We constateren dat de relatie tussen het platform NBK, en zijn opvolgers het PSRU en het Comité Kritallnachtherdenking, en het CJO rondom de Kristallnachtherdenking in Amsterdam sinds de eeuwwisseling sterk verslechterd is en heeft geresulteerd in de organisatie van twee herdenkingen. Aan welke factoren is deze ontwikkeling toe te schrijven? Bij de beantwoording maken we, zoals eerder aangegeven, onderscheid tussen institutionele factoren, positionele factoren en contextuele factoren op het culturele veld van herdenkingen van gebeurtenissen voor en tijdens de Tweede Wereldoorlog in Nederland.

Voordat we deze vraag proberen te beantwoorden, stellen we eerst vast dat in beide herdenkingen de historische gebeurtenis van de Kristallnacht centraal staat ter nagedachtenis van de Joodse slachtoffers en, wat nadien is gebleken, als voorbode voor de verschrikkingen van de Holocaust. Dit hebben de beide herdenkingen gemeenschappelijk; daarin vonden NBK en Joodse organisaties en individuen - ondanks allerlei spanningen - elkaar ook lange tijd. Tevens is het voor beide een waarschuwing voor vandaag, ook dat hebben de twee herdenkingen gemeen.

\section{Institutionele factoren}

De verslechterde relatie tussen NBK en zijn opvolgers aan de ene kant en het CJO aan de andere kant, die geleid heeft tot de organisatie van twee afzonderlijke herdenkingen, houdt allereerst verband met belangrijke verschillen tussen de beide instellingen. Zo hebben zij een zeer verschillende visie op datgene waar de Kristallnacht een waarschuwing voor is, wat weer samenhangt met verschillen in hun doelstellingen. In de CJO-herdenkingen wordt vooral gewaarschuwd voor hedendaags antisemitisme. Men roept op om alert 
te zijn voor en zich te weer te stellen tegen nieuwe uitingen van Jodenhaat, in het bijzonder in Nederland. De nadruk op antisemitisme in Nederland past geheel bij de doelstelling van het CJO om de belangen van Joden in specifiek de Nederlandse context te behartigen.

Tijdens de PSRU-herdenkingen en die van het Comité Kristallnachtherdenking trekt men de waarschuwing voor vandaag in twee opzichten breder. Ook daar keert men zich tegen nieuwe uitingen van antisemitisme in de Nederlandse samenleving, maar daar beperkt men zich nadrukkelijk niet toe. Ten eerste keert men zich tegen allerlei vormen van vreemdelingenhaat, racisme en uitsluiting, en dus niet alleen tegen antisemitisme. Sterker nog, in 2014 zei spreker Ido de Haan, hoogleraar Geschiedenis aan de Universiteit Utrecht, tijdens de herdenking van het PSRU: "De les van Kristallnacht is wat mij betreft dan ook niet dat antisemitisme en rassenhaat de wortel van alle kwaad zijn. Mensen hoeven elkaar niet aardig te vinden om te kunnen samenleven" (2014). Het grootste gevaar zag hij ontstaan wanneer, zoals dat in Nazi-Duitsland het geval was geweest tijdens de Kristallnacht, een overheid zich een verwerpelijke ideologie eigen maakt en omzet in discriminatie van en geweld jegens groepen (De Haan 2017). Kenmerkend is dat daarbij regelmatig op de discriminatie van moslims en islamofobie wordt gewezen (zie Hamburger 2016).

Zoals eerder gezegd, hierover wordt in Joodse kring verschillend gedacht. Een (groot) deel van de Joodse gemeenschap ziet islamofobie, in de zin van afkeer van moslims als moslims op grond van stereotypen en vooroordelen, en antisemitisme als vergelijkbare vormen van verwerpelijke haat jegens andere groepen, maar een ander deel ziet islamofobie en antisemitisme juist als onvergelijkbare verschijnselen en ervaart de komst en groei van de islam in Nederland als een bedreiging voor de Joodse gemeenschap en het Joodse leven in Nederland waartegen men zich moet verzetten. Men associeert moslims en de islam met de opleving van antisemitisme, die ook tot uitdrukking komt in verschillende terroristische aanslagen die in naam van de islam zijn gepleegd.

Ten tweede keert men zich in de PSRU-bijeenkomsten en die van het Comité Kristallnachtherdenking ook tegen vormen van racisme, onderdrukking en uitsluiting, inclusief islamofobie, buiten Nederland, in andere delen van de wereld. Daarbij valt op dat men zich soms ook keert tegen het optreden van Israël tegen de Palestijnen. Men wijst Israël aan als dader van ongeoorloofd geweld en onderdrukking van Palestijnen en neemt het voor hen op.

Over de Israëlisch-Palestijnse relaties wordt eveneens in Joodse kring zeer verschillend gedacht. De overgrote meerderheid van de Joden in Nederland 
steunt Israël, maar het optreden van de Israëlische regering ten opzichte van de Palestijnen wordt verschillend beoordeeld. Een gedeelte staat - in meer of minder mate - kritisch tegenover over de Israëlische politiek ten aanzien van (islamitische en christelijke) Palestijnen in Israël en de Palestijnse gebieden, een ander deel steunt de Israëlische politiek daaromtrent. Dit deel wijst dan ook verwijten aan het adres van de Israëlische regering zoals die tijdens PSRU-bijeenkomsten worden gemaakt, volstrekt van de hand. De toenmalige CJO-voorzitter Ron van der Wieken zei in dit verband in Het Parool: "De Kristallnacht wordt misbruikt om Israël zwart te maken en te haten" (Van Oordt \& Butter 2015). Ook wordt gewezen op het feit dat in tal van landen in het Midden-Oosten minderheden, inclusief Joden, christenen en islamitische minderheidsgroepen, gediscrimineerd, uitgesloten en soms vervolgd worden. Daarover, zo zegt men, wordt niet gesproken bij de andere herdenkingen, vooral het optreden van de Israëlische regering wordt bekritiseerd. Dit ziet men als selectieve verontwaardiging die grenst aan of identiek is met antisemitisme.

De thema's van discriminatie en achterstelling van moslims en Joden in vergelijkend perspectief en het Israëlisch-Palestijnse conflict hebben de organisatoren van de beide herdenkingen ver uit elkaar gedreven. In de jaren negentig vonden betrokkenen elkaar nog in een gezamenlijke Kristallnachtherdenking waarin naast het heden en verleden van de gevolgen van antisemitisme ook andere vormen van haat, discriminatie en uitsluiting aan de kaak werden gesteld, maar vanaf 2000 liepen de onderlinge spanningen steeds verder op. Mechanismen van 'selfing' en 'othering' deden hun werk. Vanaf 2010 besloot het CJO jaarlijks een eigen herdenking te organiseren. Vervolgens heeft het CJO geprobeerd deze herdenking zo sterk mogelijk te positioneren door bijvoorbeeld deze de naam van "Nationale Kristallnacht” te geven, kritiek te uiten op de PSRU-herdenkingen, en twijfel te zaaien over de politiek en persoonlijke reputatie van organisatoren en sprekers. Omgekeerd deed zich iets vergelijkbaars voor in kringen van de PSRU-herdenking. Zo ontstond een polemische en polariserende sfeer. De laatste jaren lijkt de balans van de publieke waardering en zichtbaarheid te verschuiven in de richting van de CJO-herdenking, als de aanwezigheid van vele hoogwaardigheidsbekleders bij deze herdenking en de landelijke media-aandacht voor deze herdenking de afgelopen jaren en de verminderde zichtbaarheid van PSRU-herdenking daarvan een indicatie is. 


\section{Positionele factoren}

Het ontstaan van twee herdenkingen houdt ook verband met de veranderde positie van de beide organiserende instellingen en de groeperingen die zij vertegenwoordigen in de Nederlandse samenleving. Vanaf de jaren 1960 werd het idee van Nederland als een multiculturele samenleving dominant (vgl. Vellenga 2015; Wallet 2017). Daar paste de opzet van de PSRU-herdenking in en daar sloot ook de betrokkenheid vanuit Joodse kring bij aan. De Joodse gemeenschap stond in het centrum van de Nederlandse samenleving en gold als haar morele geweten. "Het idee van de multiculturele samenleving zorgde er ook voor dat joden en andere minderheden vrijwel automatisch aan elkaar gekoppeld werden (...) Veel joden voelde zich nauw verbonden met nieuwe minderheden en zagen de strijd tegen discriminatie en racisme als een integraal onderdeel van hun eigen joodse identiteit. Antisemitisme werd in veel gevallen nog wel als een aparte categorie benoemd, maar direct verbonden met het racisme dat Surinamers, Turken en Marokkanen in de samenleving ondervonden" (Wallet 2017, 446).

Vanaf ongeveer de eeuwwisseling tekende zich een herdefiniëring van de Nederlandse samenleving af, waarbij het nationale zelfbeeld van Nederland als multiculturele samenleving naar achteren schoof ten gunste van Nederland als een (overwegend) seculier en progressief land (vgl. Vellenga 2015; Wallet 2017, 467-470). Bij dit beeld sloot het PSRU-initiatief minder goed aan en hierin kreeg ook de Joodse gemeenschap een andere positie. De historicus Bart Wallet schrijft: “Die centrumpositie van joden leek vanaf het begin van de eenentwintigste eeuw aan belang in te boeten, in de context van een terugkeer van een meer eenduidige nationale identiteit en een afscheid van multiculturele idealen. Cultureel-etnische minderheden werden geherdefinieerd in religieuze termen, waardoor ook bij de beeldvorming over Nederlandse joden de notitie van religie weer sterker naar voren komt (...) Hoewel de Tweede Wereldoorlog voor velen een moreel ijkpunt bleef, raakte die wel op de achtergrond ten faveure van nieuwe nationale, liberale concepten zoals individuele rechten en emancipatievermogen. De plaats van joden werd daardoor diffuser; zij werden soms in de context van het integratiedebat opgevoerd als voorbeeldig geïntegreerde Nederlanders, maar konden ook als een strenge, religieuze gemeenschap gezien worden met riten en gebruiken die zich slecht verhielden tot de meerderheidsmoraal. Van een centrum positie leken de Nederlandse joden weer op weg naar een meer marginale plaats, als relatief kleine en zeer diverse 'gemeenschap' in een seculiere samenleving" $(2017,483)$. In deze nieuwe positie wordt de gemêleerde Joodse gemeenschap meer op zichzelf teruggeworpen en past het dat zij haar krachten bundelde in 
de oprichting van het CJO dat zich expliciet inzet voor de behartiging van de belangen van Joden in Nederland in de publieke sfeer en ook de herdenking van de Kristallnacht in eigen, Joodse hand neemt.

\section{Contextuele factoren}

Om de dynamiek en rivaliteit van de twee herdenkingen te begrijpen, is van belang ook de rol van omstanders en buitenstaanders te onderkennen, vooral die van christelijke instellingen, moslimgroeperingen en de (lokale) overheid. Christelijke instellingen, zoals de Protestantse Kerk in Nederland (PKN), hebben de NBK-herdenking dikwijls ondersteund, maar ondersteunden later ook het CJO-initiatief. Bij de oplopende spanningen werd de druk op sprekers om niet bij de PSRU-herdenking op te treden opgevoerd. Zo zag PKN-scriba Arjan Plaisier daarvan af (PSRU 2014). Christelijke splintergroepen, zoals de sterk anti-islamitische groep Tora-Yeshua (Torah-Jezus), geleid door de zich 'christelijk-joods pastor' noemende Ben Kok, voerden een felle campagne tegen de NBK-herdenking. Leden ervan woonden de NBK-herdenking zwijgend in Isrälische vlaggen gehuld bij (Tora-Yeshua 2010).

In al deze jaren waren moslims als aparte groep bij de herdenkingen nauwelijks hoor- en zichtbaar. Yüksel (CMO) wees in 2003 op de noodzaak tot een islamitisch-Joodse dialoog. Het KMAN was weliswaar een Marokkaanse migrantenorganisatie maar heeft als zodanig de religieuze stem nauwelijks verwoord. Menebhi was een seculiere denker met een uitgesproken links profiel die aanvankelijk weinig zag in de rol van de islam. Later veranderde hij enigszins van inzicht. In 2002 liet hij optekenen dat hij en de linkse beweging een historische vergissing hadden gemaakt. ${ }^{10}$ Ze hadden religie ten onrechte beschouwd als opium van het volk en derhalve niet als een constructieve factor in maatschappelijke veranderingen die de beweging beoogde. Onder invloed van de ontwikkelingen en het denken van de Libanese filosoof en communist Husayn Muruwwa moest links zich volgens Menebhi heroriënteren op de rol van de islam als activerend beginsel, los van de fundamentalistische interpretaties. De rol van (seculier) links was in zijn ogen uitgespeeld.

De stedelijke autoriteiten toonden zich bezorgd over de waardigheid van de herdenking. Op verschillende momenten bestond een afstemming tussen de organisatoren van de herdenkingen en de stedelijke overheid. Het stadbestuur was betrokken bij afspraken, ook rond de inhoud van de bijdragen van de sprekers (Gemeenteraad Amsterdam 2015). Volgens Ensel bemoeide de overheid zich zelfs te veel met deze zaak..$^{11}$ In 2010 vonden, zoals we boven zagen, voor het eerst de twee herdenkingen op dezelfde dag plaats en werd er wederzijds kritiek geleverd. De overheid gaf het signaal af van betrokkenheid 
bij de beide initiatieven. De goede relaties tussen de betrokken groepen raakten aan de verantwoordelijkheid van de overheid voor de sociale cohesie in de stad. Burgemeester Eberhart Van der Laan woonde de CJO-herdenking bij en wethouder Andrée van Es de PSRU-herdenking. Beide bestuurders lieten blijken het belangrijk te vinden dat de beide herdenkingen samen zouden gaan. Tot ongenoegen van de organisatoren van de PSRU-herdenking riep de burgemeester deze laatste groep op om zich aan te sluiten bij de CJO-herdenking. Dit deed bij hen de indruk ontstaan dat de gemeente niet neutraal was. De laatste jaren worden vertegenwoordigers van de gemeente dan ook niet meer uitgenodigd voor de PSRU-herdenking (interview Hijmans). Het beleid van de gemeente blijft erop gericht de verschillende herdenkingen in vrijheid en waardig te laten verlopen (Gemeenteraad Amsterdam 2015; interview Van Slooten).

Voor een juist begrip van de dynamiek en uiteindelijk de tweespalt tussen NBK/PSRU aan de ene kant en een aantal Joodse organisaties, zoals CIDI, en, vanaf 1997, het CJO aan de andere kant rond de Kristallnachtherdenkingen in Amsterdam is het van belang ze ook te zien in de bredere context van ontwikkelingen in Nederland en het Midden-Oosten sinds de jaren tachtig van de vorige eeuw. In die jaren werd in Nederland in een seculier getinte setting gezamenlijk gestreden tegen opkomende vreemdelingenhaat, antisemitisme en racisme. Antisemitisme en geweld jegens en de uitsluiting van migranten met een islamitische achtergrond werden gezien als parallelle verschijnselen. Verder was in die jaren de steun voor Israël en de Israëlische politiek in Nederland nog steeds vrij groot, hoewel de politieke houding ten opzichte van Israël kritischer was dan in de decennia daarvoor (Snel 2008). De steun voor de Palestijnse zaak groeide. Onder invloed van bijvoorbeeld het bloedbad in de Palestijnse vluchtelingenkampen Sabra en Shatila, dat in 1982 ten tijde van het beleg door het Israëlische leger van Beiroet plaatsvond, nam de populariteit van Israël in Nederland af (Malcontent 2018).

Vanaf de jaren tachtig en vooral de jaren negentig veranderde de rol van de islam en moslims in Nederland en Europa alsmede de relatie tussen Israël en de Palestijnen. Sinds het einde van de jaren tachtig werd in Nederland en ruimer, Europa, de religieuze identiteit van migranten uit moslimlanden steeds belangrijker. De islam werd steeds meer zichtbaar in het openbare leven; 'buitenlanders' en 'migranten' werden ‘moslims' (Vellenga 2009). De toenemende publieke zichtbaarheid van de islam in Europa en de politieke rol van de islam in het Midden-Oosten riep heftige weerstanden op. De angst werd vergroot door aanslagen in naam van de islam. Het verschijnsel en de term 'islamofobie' deden hun intrede. 
Daarnaast was aan het eind van de jaren negentig de teleurstelling groot over het vastlopen van het vredesproces na de hoopvolle ondertekening van de Oslo-akkoorden in 1993 (Malcontent 2018). In 2000 brak de Tweede Intifada, de Palestijnse opstand, uit. Diverse malen werd in Nederlandse en Europese steden massaal geprotesteerd tegen het geweld van het Israëlische leger. In het jaar 2000 werd voor het eerst een verband gelegd tussen anti-Joodse c.q. anti-Israëlische uitingen van Marokkaanse jongeren in Amsterdam en het Israëlische optreden tegen de Intifada.

De opkomst van het verschijnsel 'islamofobie' alsmede het mislukken van het Oslo-vredesproces in 2000 en het repressieve beleid van de Israëlische regering ten aanzien van Palestijnen werden zeer verschillend beoordeeld en waren controversieel. Deze twee thema's hebben gewerkt als splijtzwammen tussen degenen die betrokken waren bij de herdenking van de Kristallnacht in Amsterdam en hebben er uiteindelijk mede toe geleid dat er jaarlijks twee in plaats van een herdenking plaatsvinden in deze stad.

\section{Tot besluit}

De twee in dit artikel besproken herdenkingen vinden plaats in het culturele veld van herdenkingen in Nederland van gebeurtenissen voorafgaande en tijdens de Tweede Wereldoorlog. We hebben gezien dat de dynamiek en rivaliteit tussen deze twee verband houden met verschillen tussen de organisatoren van de herdenkingen, verschillen in maatschappelijke positie en met omgevingsfactoren.

De vraag is vervolgens wat het naast elkaar bestaan van de twee Kristallnachtherdenkingen in Amsterdam over Joods-islamitische betrekkingen in Nederland voor gevolgen heeft. Uit onze analyse blijkt dat de verdeeldheid tussen de organisatoren van de herdenkingen slechts ten dele samenvalt met verschillen van mening tussen Joden en moslims. Omdat de PSRUherdenking het ook opneemt voor de moslims die achtergesteld worden in de Nederlandse samenleving en solidariteit betoont met Palestijnen met wie veel Nederlandse moslims zich verbonden voelen en de CJOherdenking vooral op de gevaren van antisemitisme in verleden en heden voor de Nederlandse context aan de kaak wil stellen, zullen veel moslims extra sympathie hebben voor de wijze waarop in de PSRU-herdenking ook aandacht wordt besteed aan de situatie van de Palestijnen. Joden die sympathie hebben voor deze benadering herkennen zich daarin. Andere Joden, waarschijnlijk de meesten, zullen zich vooral herkennen in de door 
het CJO georganiseerde herdenking. Overigens zullen ook sommige moslims sympathie hebben voor deze herdenking. De PSRU-herdenking en die van het Comité Kristallnachtherdenking werden ondersteund door het Steuncomité Israëlische Vredes- en Mensenrechtenorganisaties (SIVMO) en Een ander joods geluid (EAJG). Lange tijd was de Joodse ooggetuige van de Kristallnacht en verzetsstrijdster Mirjam Ohringer actief betrokken. Het KMAN zelf was, vanwege zijn seculiere, linkse signatuur, nauwelijks representatief voor de opvattingen onder moslims in Nederland. Bij de jaarlijkse Kristallnacht herdenking van het CJO is het CMO aanwezig geweest. Ook waren sprekers met een achtergrond in de Marokkaanse gemeenschap, zoals Tweede Kamervoorzitter Khadija Arib in 2017 en de Rotterdamse burgemeester Ahmed Aboutaleb, erbij aanwezig.

De verschillen tussen de herdenkingen zijn niet zozeer etnisch-religieus van aard, het conflict daarover is meer gelegen in politieke factoren die scheidslijnen trekken binnen verschillende gemeenschappen, maar vooral binnen de Joodse, en die doorwerken binnen het culturele veld van herdenkingen (vgl. Malcontent 2018). De ene partij wil een verbinding leggen tussen de Kristallnacht in 1938 en hedendaagse vormen van antisemitisme, maar ook andere vormen van discriminatie, uitsluiting en racisme in Nederland - inclusief islamofobie - en ook aandacht schenken aan het optreden van Israël tegen de Palestijnen, de andere partij wil vooral een verbinding leggen tussen de Kristallnacht en hedendaagse uitingen van antisemitisme die de Joodse gemeenschap in Nederland bedreigen.

Sinds 2010 wordt er in Amsterdam geen gemeenschappelijke Kristallnachtherdenking georganiseerd. Wellicht is dat een teken van de huidige tijd waarin (politieke) polarisatie de boventoon voert. Veel mensen zullen het betreuren dat het herdenken van een afschuwwekkende gebeurtenis als de Kristallnacht tot verdeeldheid leidt. Anderen wijzen erop dat de beide herdenkingen recht van bestaan hebben en elkaar wellicht ook aan kunnen vullen omdat ze verschillende perspectieven aan het licht brengen. Met betrekking tot Israël en Palestina wijzen sommige onderzoekers op de mogelijkheid voor de betrokken groepen om in het lijden dat Palestijnen tijdens de Nakba (de catastrofe) trof en de Joden tijdens de Holocaust een begin van wederzijds begrip te zien, en niet alleen als elkaar uitsluitende ervaringen (Bashir \& Goldberg 2014). De Amsterdamse burgemeester Eberhard van der Laan riep bij verschillende gelegenheden op tot een verzoening tussen de organisatoren van beide herdenkingen. Ondanks de pogingen van verschillende zijden lijken de polarisatie tussen én binnen de betrokken groepen en hun uiteenlopende belangen vooralsnog te sterk om de verschillen te overbruggen. 


\section{Noten}

1 Dit artikel komt voort uit het onderzoeksproject Delicate Relations: Jews and Muslims in Amsterdam and London met projectnummer 327-25-001, dat wordt gesubsidieerd door de Nederlandse Organisatie voor Wetenschappelijk Onderzoek (NWO), het Ministerie van Veiligheid en Justitie en het Ministerie van Sociale Zaken en Werkgelegenheid. De auteurs danken Emma Post en Shannon Witlox, studenten religiewetenschappen, voor de zeer waardevolle ondersteunende werkzaamheden die zij als student-assistenten hebben verricht.

2 De benaming 'Kristallnacht' wordt in Nederland algemeen gebruikt. De oorsprong van het woord is het Duitse 'Reichskristallnacht', een term die door het Naziregime werd geïntroduceerd. Vanwege die verhullende en besmette lading wordt in Duitsland de laatste jaren meer de aanduiding 'Reichspogromnacht' gebruikt (vgl. Klemperer 2007).

3 De genoemde aantallen zijn schattingen. Een belangrijke bron is McCullough \& Wilson $(2014,2)$. Zie verder: Goldberg \& Hazan $(2015,324)$, Caestecker \& Moore (2010, 276) en Kaplan $(1999,123)$.

4 Een overzichtvan deherdenkingen in Amsterdam tussen 1992 en 2015 te vinden op: NBK (2015), http://www.herdenkingkristallnacht.nl/index.html en vanaf 2016 op Comité Kristallnacht Herdenking (2017, 2018), http://kristallnachtherdenking.blogspot.com/. Zie verder: Perdu (2017), https://perdu.nl/nl/r/herdenk-de-kristallnacht/ en Perdu (2018), https://www.perdu.nl/nl/r/kristallnachtherdenking-2018/.

5 Het heeft in het algemeen zeer lang geduurd voordat er in Nederland publieke erkenning kwam voor de Jodenvervolging, die in Nederland buitengewoon vernietigend is geweest: van de 140.000 personen die door de Duitsers als Jood waren geregistreerd, zijn volgens Happe 102.994 naar de concentratiekampen gedeporteerd (2018).

6 In Ensel \& Gans $(2017,485)$ wordt gesteld dat de herdenking mede een reactie was op de aanslag in het Duitse Solingen waarbij vijf Turkse migranten omkwamen. Dat was echter op 25 en 26 mei 1993, een jaar later. In Ensel $(2014,195)$ wordt wel de aanslag in Rostock als aanleiding voor de eerste herdenking genoemd.

7 Tijdens het interview met Ronny Naftaniel gaf deze overigens aan indertijd niet namens de Liberaal Joodse Gemeente te hebben gesproken, maar als directeur van het CIDI.

8 Wat opvalt in de berichtgeving in De Waarheid is dat het initiatief als een doorbraak werd gezien; zeer verschillende groepen stelden zich erachter. Verder valt op dat de termen 'islam' en 'islamofobie' niet vallen. Waar we vandaag de dag zouden spreken over moslims gaat het hier over buitenlanders. De component islam is ook in de zelfbeschrijvingen van de organisaties afwezig.

9 Naar aanleiding van een opleving van xenofobisch geweld in Europa, zoals in Rostock, werden in 1992 twee conferenties gehouden over antiracisme. Europese jongeren kwamen in Straatsburg bijeen om kennis te delen over het tegengaan van fascisme, racisme en antisemitisme. Hieruit is UNITED geboren, met het doel om steun te verlenen aan verschillende Europese organisaties. Daarnaast organiseert UNITED zelf verschillende campagnes, waaronder de 'International Day Against Fascism and Antisemitism'. Sinds 1992 ondersteunt ze organisaties die op 9 november een evenement organiseren "to commemorate the past and to protest against contemporary forms of fascism and antisemitism." (UNITED).

10 De uitspraak van Menebhi wordt geciteerd in Ron Haleber en Alex de Meijer (2002).

11 Ensel is van mening dat de overheid een bedenkelijke, censurerende rol speelde, niet alleen rond Menebhi in 2000, maar ook rond de Joodse verzetsstrijdster en lid van het Amsterdamse 4 en 5 mei comité, Mirjam Ohringer (2014, 191-201). 


\section{Literatuur}

Bashir, B. \& A. Goldberg (2014),

Deliberating the Holocaust and the Nakba. Disruptive Empathy and Binationalism in Israel/Palestine, in: Journal of Genocide Research, 16 (1), 77-99.

Baumann, G. (2004),

Grammars of Identity/Alterity: a Structural Approach, in: Baumann, G. \& A. Gingrich (eds.), Grammars of Identity/Alterity: a Structural Approach, New York: Berghahn Books.

Bleich, A. (1988),

Gruwelsprookjes uit naam der solidariteit, in: De Groene Amsterdammer, 13 juli 1988.

Bourdieu, P. (1986),

The Forms of Capital, in: Richardson, J. (ed.), Handbook of Theory and Research for the Sociology of Education, New York: Greenwood, 241-258.

Bourdieu, P. (1990),

The Logic of Practice, Cambridge, UK: Polity Press.

Bourdieu, P. (ed.) (1999),

The Weight of the World: Social Suffering in Contemporary Society, Stanford: University Press.

Brandsma, B. (2019),

Polarisatie. Inzicht in de dynamiek van het wij-zij denken, Schoonrewoerd: BB in Media. CIDI (2011), Jaarverslag 2011, https://www.cidi.nl/jaarverslag-2011/

Caestecker, R. \& B. Moore (eds.) (2010),

Refugees from Nazi Germany and the Liberal European States, New York: Berghahn Books.

Comité Kristallnacht Herdenking (2017, 2018), http://kristallnachtherdenking.blogspot.com/ (Geraadpleegd op 22 juli 2019).

De Waarheid (1980), Amsterdams initiatief doorbreekt scheidslijnen, in: De Waarheid, 12 december 1980.

De Waarheid (1980),

Massale demonstratie in Amsterdam, in: De Waarheid, 15 december 1980.

De Waarheid (1980),

Optreden nodig tegen fascisme, racisme en antisemitisme, in: De Waarheid, 16 december 1980.

Ensel, R. (2014),

Haatspraak. Antisemitisme - een 21ste-eeuwse geschiedenis, Amsterdam: Amsterdam University Press. 
Ensel, R. \& E. Gans (eds.) (2017),

The Holocaust, Israel and the Jew. Histories of Antisemitism in Postwar Dutch Society, Amsterdam: Amsterdam University Press.

Frijda, N.H. (1997),

Commemorating, in: Pennebaker, J.W., D. Paez \& B. Rimé, (eds.), Collective Memory of Political Events. Social Psychological Perspectives, Mahwah: Lawrence Erlbaum Associates, 103-125.

Gemeenteraad Amsterdam (2015),

Raadsnotulen 4 november 2015, Amsterdam: Gemeenteraad, 24-25.

Goldberg A. \& H. Hazan (eds.) (2015),

Marking Evil. Holocaust Memory in the Global Age, New York: Berghahn.

Haan, I. de (2017),

Toespraak tijdens Kristallnachtherdenking, https://www.nieuwwij.nl/themas/toespraakido-de-haan-tijdens-kristallnachtherdenking/ (Geraadpleegd op 22 juli 2019).

Haleber, R. \& A. de Meijer (2002),

Revolutionairen in de moskee, in: Grenzeloos (6), http://members.chello.nl/rphaleber/ int-abdou.html (Geraadpleegd op 22 juli 2019).

Hamburger, J. (2016),

Toespraak tijdens Kristallnachtherdenking, https://www.platformtegenvreemdelingen haat.nl/archief/toespraak-jaap-hamburger-kristallnachtherdenking-2016/index.html (Geraadpleegd op 22 juli 2019).

Happe, K. (2018),

Veel valse hoop. De Jodenvervolging in Nederland 1940-1945, Amsterdam: Atlas Contact. Het Parool (1989),

Strijd tegen discriminatie stokt. Marokkanen en Turken hebben bezwaar tegen joodse organisatie, in: Het Parool, 26 september 1989.

Het Parool (2010),

Kristallnacht onwaardig, in: Het Parool, 10 november 2010.

Hervieu-Léger, D. (2000),

Religion as a Chain of Memory, New Brunswick: Rutgers University Press.

Hijmans, M.J.,

http://abu-pessoptimist.blogspot.com/ (Geraadpleegd op 22 juli 2019).

Hijmans, M.J. (2015),

Zij pleit tegen geweld, maar geldt als antisemiet en terrorist, https://www.sivmo.nl/ data/upload/files/hanin-zoabi.pdf (Geraadpleegd op 22 juli 2019).

Kaplan, M. (1999),

Between Dignity and Despair. Jewish Life in Nazi Germany, Oxford: Oxford University Press. 
Katz, E. (2015),

The Burdens of Brotherhood: Jews and Muslims from North Africa to France, Cambridge, MA: Harvard University Press.

Klemperer, V. (2007),

Lingua Tertii Imperii, Notizbuch eines Philologen (eerste uitgave 1947), Ditzingen: Reclam Philipp Jun.

Macdonald, S. (2005),

Commemoration the Holocaust. Reconfiguring national identity in the twenty-first century, in: Litter, J. \& R. Naidoo (eds.), The Politics of Heritage. Legacies of 'race', London/New York: Routledge, 49-68.

Malcontent, P. (2018),

Een open zenuw. Nederland, Israël \& Palestina, Amsterdam: Boom.

Menebhi, A. (1989),

Kman, in: NRC Handelsblad, 19 oktober1989, 4.

McCullough, C. \& N. Wilson (eds.) (2014),

Violence, Memory, and History: Western Perceptions of Kristallnacht, London: Routledge.

Mol, H. (2004),

Politie kijkt toe bij vlagverbranding; Circa 100 demonstranten protesteren op de Dam tegen liquidatie Yassin, in: NRC Handelsblad, 29 maart 2004.

NBK (2015),

http://www.herdenkingkristallnacht.nl/index.html (Geraadpleegd op 22 juli 2019).

NRC Handelsblad (1989),

Marokkanen niet met Cidi in organisatie, in: NRC Handelsblad, 26 september 1989.

Oordt, R. van \& E. Butter (2015),

Gezamenlijk herdenken definitief van de baan, op http://www.republiekalloch tonie.nl/blog/opinie/gezamenlijk-herdenken-kristallnacht-definitief-van-de-baan, 31 oktober 2015 .

Perdu (2017),

https://perdu.nl/nl/r/herdenk-de-kristallnacht/ (Geraadpleegd op 22 juli 2019).

Perdu (2018),

https://www.perdu.nl/nl/r/kristallnachtherdenking-2018/ (Geraadpleegd op 22 juli 2019).

PSRU (2014),

http://www.platformtegenvreemdelingenhaat.nl/nieuws/verklaring-m-b-tkristallnachtherdenking/index.html (Geraadpleegd op 22 juli 2019).

Snel, J.D. (2014),

Nederland en de band met Israël. Sympathie voor een jonge staat, in: Historisch Nieuwsblad, (5), https://www.historischnieuwsblad.nl/nl/artikel/10671/nederland-ende-band-met-israel.html (Geraadpleegd op 22 juli 2019). 
Solidariteitsplatform met de volksopstand in Palestina (mei 1988),

Intifada special, Amsterdam: SVP.

Tora-yeshua (2010),

https://tora-yeshua.nl/2010/11/verslag-kristallnachtherdenking-2010-amsterdam (Geraadpleegd op 22 juli 2019).

UNITED,

http://www.unitedagainstracism.org/campaigns/annual-campaigns/internationalday-against-fascism-and-antisemitism/ (Geraadpleegd op 22 juli 2019)

Valk, I. van der (1996),

Van migratie naar burgerschap. Twintigjaar Komitee Marokkaanse Arbeiders in Nederland, Amsterdam: Instituut voor Politiek en Publiek.

Vellenga, S.J. (2009),

Islam in Nederland: trends en toekomst, in: Vellenga, S.J. et al. (red.), Mist in de polder. Zicht op ontwikkelingen omtrent de islam in Nederland, Amsterdam: Aksant, 13-30.

Vellenga, S.J. (2015),

Ritual Slaughter, Animal Welfare and the Freedom of Religion: A Critical Discourse Analysis of a Fierce Debate in the Dutch Lower House, in: Journal of Religion in Europe, $8,210-234$.

Verter, B. (2003),

Spiritual Capital Theorizing Religion with Bourdieu against Bourdieu, in: Sociological Theory, 21 (1), 150-174.

Wallet, B. (2017),

Tussen Marge en Centrum. Joden in Naoorlogs Nederland, in: Blom, H., D. Wertheim, H. Berg \& B. Wallet (red.), De Geschiedenis van de Joden in Nederland, Amsterdam: Boom, pp. 407-485.

Weezel, N. van (2017).

Thuis bij de vijand. Moslims en joden in Nederland, Amsterdam: Balans. 